\title{
The Principle of Equal Rights in the Context of the Covid-19 Pandemic as a Factor Influencing the Sustainable Development of Ukraine
}

\author{
By Gulnara Dzhumageldiyeva ${ }^{1}$, Yuliia Serebriakova ${ }^{2}$, Bogdan Derevyanko $^{3}$, \\ Olena Zubatenko ${ }^{4}$, Dmytro Selikhov ${ }^{5}$
}

\begin{abstract}
The article discusses the implementation of the principle of equal rights in the context of the COVID19 pandemic in Ukraine. The peculiarities of applying this principle in relation to human rights and the rights of companies have been investigated. The article analyzes the state of compliance with the principle of equal rights in the diagnostics (testing) and treatment of different categories of patients in territories with different legal regimes. The study revealed de jure violations of equality in the normative definition of categories of citizens entitled to free testing, as well as de facto discrimination of citizens based on their place of residence when they cross the demarcation line between the controlled and uncontrolled territory of Ukraine. The state of ensuring equal economic rights of companies and an acceptable level of competition in the event of quarantine measures have been investigated. The general parameters of the relationship between the state and business and the limits of state intervention in entrepreneurial activity in the context of the pandemic have been determined. Characteristic features of discrimination against certain categories of the population and companies due to the establishment of quarantine have been revealed.
\end{abstract}

Keywords: COVID-19, the principle of equal rights, sustainable development, healthcare, diagnostics, freedom of movement, competition, freedom of contract

\section{Introduction}

The COVID-19 pandemic has clearly demonstrated the vulnerability of the public health systems of the vast majority of countries and their unwillingness to face challenges based on sustainability principles. The virus served as a kind of a test that showed that despite the efforts made in the field of healthcare the level of coverage by medical services and access to safe and affordable medicines and vaccines was insufficient, and the management system in the field of scientific research and development of vaccines was extremely unsatisfactory.

\footnotetext{
| 1 Doctor of Law, Senior Researcher, Professor, Faculty of Public Administration and Law, Department of Law and law enforcement activities, State University "Zhytomyr Polytechnic"

${ }^{2} \mathrm{PhD}$, Associate Professor, Faculty of Sociology and Law, Department of Information, Commercial and Administrative Law, National Technical University of Ukraine «Igor Sikorsky Kyiv Polytechnic Institute», Ukraine

3Doctor of Law, Professor, Academician F.H. Burchak Scientific Research Institute of Private Law and Entrepreneurship of the National Academy of Legal Sciences of Ukraine

${ }^{4} \mathrm{PhD}$, Associate Professor, Chief adviser of Law firm "SNS Partners"

${ }^{5} \mathrm{PhD}$, Associate Professor, Faculty of Training Specialists for Preventive Activity Units, Department of Theory and History of State and Law, Dnipropetrovsk State University of Internal Affairs
} 
The speed of the spreading virus and limited resources of health facilities, the lack of vaccines against COVID-19, and the uncompetitive order of their supply force a constant and cynical choice of the highest priority between different populations within the country and between countries at the global level, which was described by the World Health Organization as a situation "on the verge of a catastrophic moral failure" (Tedros, 2021). The pandemic showed the main limitations of health systems, lack of readiness to respond to the outbreak, and inequality in healthcare among different social groups of the population (Bautista-González, Werner-Sunderland, Pérez-Duarte Mendiola, EsquincaEnríquez-de-la-Fuente, Bautista-Reyes, Maciel-Gutiérrez, Murguía-Arechiga, VindrolaPadros \& Urbina-Fuentes, 2021).

Under these conditions, the issue arises about the functional purpose of legal principles, in particular, the principle of equal rights, which is the central principle of sustainable development ("No one will be left behind") (Sachs, Schmidt-Traub, Kroll, Lafortune, Fuller \& Woelm, 2020), and its impact on public health policy based on the principles of sustainable development (by the example of Ukraine).

First, it is important whether the principle of equal rights has been respected in national legislation against COVID-19. Taking into account specific conditions for the formation and implementation of the state policy against this pandemic, namely the need for an urgent response, fragmentary information about the main parameters of the threat, etc., the degree of compliance with the specified principle may indicate the presence/absence of discrimination on any grounds in national legislation under any conditions. Second, the reasons for violating the principle of equal rights are important. Are they within the competence of the rule-making body, which is the most important factor in the success and failure in the fight against COVID-19 (Fisher \& Shapiro, 2021), and can be eliminated without changing the general legislation? On the other hand, are we talking about the shortcomings of the national interpretation of this principle, because of which this pandemic undermines the system of guarantees of equality?

It is obvious that before the COVID-19 pandemic, the implementation by Ukraine of such a sustainable development goal as ensuring a healthy lifestyle and well-being of people of all ages (hereinafter referred to as Goal 3) had the lowest results. Thus, according to the data of the Sustainable Development Report 2020, the overall progress of Ukraine towards achieving Goal 3 is critical, the main problems remain (Sachs, Schmidt-Traub, Kroll, Lafortune, Fuller \& Woelm, 2020). Meanwhile, the UN summit back in 2015 planned it to achieve Goal 3 by performing nine tasks, one of which is the fight against epidemics and infectious diseases. In the context of the COVID-19 pandemic, the implementation of this task becomes particularly important. D. Drezner rightly claims that no event in the world since the Second World War has had such a noticeable impact on human behavior in such a short period of time (Drezner, 2020).

However, the National Sustainable Development Goals of Ukraine, in order to achieve Goal 3, provide for the fight only against HIV/AIDS and tuberculosis epidemics, as well as reducing premature deaths from non-communicable diseases. Thus, before the COVID19 pandemic, Ukraine did not consider the fight against infectious diseases as an element of the national mechanism for ensuring sustainable development, which led to the absence of even an approximate theoretical perspective of an algorithm for countering the spread of this disease in compliance with basic human rights. At the same time, compliance with 
the principle of equal rights and freedoms of citizens in the context of the pandemic is crucial, because, as noted in the Sustainable Development Report 2020, COVID-19 dramatically exacerbates income inequality and other forms of inequality, the poor suffer most from infectious diseases and die, and struggle more to make ends meet (Sachs, Schmidt-Traub, Kroll, Lafortune, Fuller \& Woelm, 2020).

\section{Literature Review}

Despite the relatively short period of existence of such an epidemiological situation in the world, a significant amount of scientific research has been carried out in this area. In particular, D. Drezner paid attention to the issue of the distribution of world power and interests during COVID-19, its influence on world politics (Drezner, 2020); the issue of diplomacy in the health sector was studied by T. Fazal (Fazal, 2020); the results of the impact of COVID-19 on policy in different countries were presented by P. Lipscy (Lipscy, 2020). Some aspects related to the inequality of the health care system (by the example of Mexico) were studied by E. Bautista-González, J.Werner-Sunderland, P. PérezDuarte Mendiola, C. Esquinca-Enríquez-de-la-Fuente, D. Bautista-Reyes, M. MacielGutiérrez, I. Murguía-Arechiga, C. Vindrola-Padros, M. Urbina-Fuentes (BautistaGonzález, Werner-Sunderland, Pérez-Duarte Mendiola, Esquinca-Enríquez-de-la-Fuente, Bautista-Reyes, Maciel-Gutiérrez, Murguía-Arechiga, Vindrola-Padros \& Urbina-Fuentes, 2021). The issues of observance of the rights of healthcare workers during the pandemic (by the example of Spain) were investigated by J.Repullo (Repullo, 2021).

The competence of government agencies and the specifics of its implementation in emergencies, such as pandemics, was analyzed by E. Fisher, S.A. Shapiro, R. Hambleton (Fisher \& Shapiro, 2021; Hambleton, 2020). K. Georgieva, F. J. Díez, R. Duval, D. Schwarz evaluated the impact of COVID-19 on the state of global competition and the prospects for a return to normal economic functioning in the post-pandemic period (Georgieva, Díez, Duval \& Schwarz, 2021). M. Goldman justifies trends regarding changes in the ratio between market and government impact on the economy as a result of COVID-19 (Goldmann, 2020). V. Zolka, O. Tsarenko, I. Kushnir, S. Tsarenko, R. Havrik conducted research on the impact of the COVID-19 pandemic on human rights, in particular, the right to freedom of movement and choice of residence (Zolka, Tsarenko, Kushnir, Tsarenko \& Havrik, 2021). K. Hoernke studied the problems of increasing inequality during the COVID-19 pandemic (Hoernke, 2020). A. Lebret explored the limits of a state's right to deviate from human rights in a state of emergency and the terms of such deviation in the context of COVID-19 (Lebret, 2020). S. Amadasun investigated reasons and implications of human rights violations are caused by the COVID-19 pandemic in Africa (Amadasun, 2020).

\section{Methodology}

Structurally, the research is divided into an analysis of compliance with the principle of equal human rights in the business sphere.

Compliance with the principle of equal human rights is investigated by the example of the right to information and treatment for COVID-19. Taking into account the purpose of 
the study, we carried out a comparative analysis of the rights of, first, vulnerable groups of the population (elderly people, residents of rural areas), as well as residents of the temporarily occupied territories, who, crossing the demarcation line, find themselves on the territory controlled by Ukraine and have the opportunity to exercise their rights as citizens Ukraine.

Equality of rights in the field of business during the COVID-19 pandemic is studied by the example of the implementation of the right to entrepreneurial activity by companies in various sectors of the economy. The analysis of the compliance with the principle of equality when establishing prohibitions and restrictions of this right has been carried out in the context of the requirements of the Convention for the Protection of Human Rights and Fundamental Freedoms, under which the possibility of deviating from the general principle of equality is conditioned by exceptional conditions, the adequacy of the degree of threat, and compliance with other international obligations.

\section{Results and Discussion}

The principle of equality of human rights is a fundamental value and a constitutional principle of the rule of law. The equality of the rights of every person is enshrined in international acts ratified by Ukraine, in particular, Articles 1, 2, 7 of the Universal Declaration of Human Rights (United Nations General Assembly, 1948), Article 14 of the 1950 Convention for the Protection of Human Rights and Fundamental Freedoms and Protocol 12 thereto (Council of Europe, 1950), Articles 14, 26 of the 1966 International Covenant on Civil and Political Rights (United Nations General Assembly, 1966). The right of every citizen to have equal constitutional rights and freedoms regardless of religious beliefs, social origin, property status, gender and other characteristics is guaranteed by Article 24 of the Constitution of Ukraine (Verkhovna Rada of Ukraine, 1996).

Moreover, article 8 of the Declaration on the Right to Development, approved by the UN General Assembly Resolution No. 41/128 of December 4, 1986, notes the obligation of states to take all necessary measures to implement the right to development and ensure access to health care and imposes on the state the obligation to conduct economic and social reforms to prevent social injustice (United Nations General Assembly, 1986). However, many challenging issues regarding the implementation of the principle of equal rights of citizens to health care and medical care have emerged during the COVID-19 pandemic.

Article 49 of the Constitution of Ukraine guarantees everyone the conditions for effective and accessible healthcare and ensuring epidemic well-being (Verkhovna Rada of Ukraine, 1996). Achieving this goal is possible provided timely detection of cases of COVID-19 infection, information on available medical services to combat this disease and the procedure for obtaining them, proper treatment of the disease, access to information on drug reserves necessary to carry out measures aimed at preventing the emergence and spread of COVID-19.

To detect cases of COVID-19 infection, the corresponding testing is carried out at the expense of public funds or citizens' own funds. Persons eligible for such tests at the expense of public funds include: 1) persons who seek medical assistance and have signs of 
COVID-19; 2) persons who have had contact with a person with COVID-19; 3) healthcare and other professionals who work in healthcare institutions providing medical care to patients with COVID-19; 4) persons taking measures to prevent the spread of COVID19, in particular to employees of the National Police and the National Guard (Verkhovna Rada of Ukraine, 2000). The last two categories are tested regularly, regardless of whether they have had contact with a person infected with COVID-19. In addition to these persons, persons with symptoms of other acute respiratory infections, symptoms of pneumonia, and persons subject to scheduled hospitalization have the right to free testing (Ministry of Health of Ukraine, 2020).

Thus, quite a limited number of people have the right to free testing. At the same time, such persons include not all persons whose testing is extremely necessary for an epidemiological search for COVID-19 cases, in particular, persons with chronic diseases, the elderly, persons working in public transport or with groups of children, etc. Moreover, among healthcare professionals, only those working in healthcare institutions providing medical care to patients with COVID-19 are eligible for a free test. Therefore, such persons do not include X-ray laboratory technicians, family doctors who often come into contact with persons with COVID-19 who do not yet have a confirmed diagnosis. This approach indicates the inequality of citizens in terms of the right of everyone to medical care and epidemiological well-being because it deprives persons who carry out measures related to preventing the spread of COVID-19 and are more likely to become infected with it the right to testing at the expense of public funds.

It is necessary to state that there is no statistical data on the number of tests performed at the citizens' own expense and public expense. We admit that such statistical information would not be pleasant. At the same time, regular testing has not been introduced for such persons to detect cases of Covid-19 infection at the expense of public funds (Verkhovna Rada of Ukraine, 2000).

For vulnerable groups of the population during an epidemic, the state should establish a special status that provides for broader rights and guarantees. At the same time, the existence of such a status cannot be considered discrimination against other groups of citizens. Under such circumstances, the task of a state governed by the rule of law should be to prevent the existence of different levels of protection for citizens. The state should organize measures to counteract the spread of COVID-19 in such a way as to prevent a significant increase in cases among the vulnerable categories of citizens mentioned above. This logic is the basis for decisions on the vaccination procedure. In particular, the roadmap for the introduction of the vaccination identifies nine priority groups that cover all the most vulnerable groups of the population (Ministry of Health of Ukraine, 2020). Thus, equality does not exclude the existence of inequality of citizens in society. At the same time, it does not allow discrimination among citizens with equal status in a certain situation. We are convinced that ensuring the implementation of the principle of equality in determining the circle of people eligible for free testing for COVID-19 will allow isolating the majority of cases in a timely manner and preventing the spread of this disease. Another important aspect of the principle of equality in the event of a pandemic is the implementation of the right to treatment. The rapid increase in disease incidence has become a serious challenge for healthcare institutions in Ukraine. Ukraine has focused efforts to ensure the implementation of measures aimed at preventing the occurrence and 
spread of COVID-19, which allowed providing citizens with appropriate medical services to a certain extent. Thus, daily reports on the situation with COVID-19 in Ukraine indicate that there is no shortage of places in hospitals.

The situation with the provision of medicines is somewhat different. Analysis of information on the availability of medicines in healthcare institutions showed that there were often cases of lack of necessary medicines, thus indicating a low level of planning of their purchases, accounting, and distribution by public authorities and/or local governments, which are responsible for the management in the field of health care in general and countering the spread of the COVID-19 pandemic in particular (National Health Service of Ukraine, 2021).

Funding for the treatment of one patient is carried out under standard protocols, which on average is designed to treat a patient for 10 days and is the same for each patient. It is obvious that the treatment of a patient with chronic diseases is usually longer and requires more medications. In such cases, doctors have a choice: to provide the available medicines to a new patient or a patient who has chronic diseases and is continuing treatment in the hospital. That is why today law enforcement practice has cases when patients who are not "chosen" by a doctor are forced to buy medicines at their own expense, which testifies to the discrimination of citizens depending on health status, age, or other characteristics that do not correspond to the essence of the principle of equality.

Whether the citizens receive medical care significantly depends on their information about the available medical services to counter COVID-19 and the procedure for obtaining them. We agree with J.R. Repullo concerning the risks of disorientation of social consciousness during the new phase of the pandemic due to incorrect receipt of messages from public health authorities (Repullo, 2021). Today in Ukraine, it is possible to inform the population about the prevention of the disease, which is carried out by the mass media, through announcements in public places (station, shop, public transport), outdoor advertising. Information about the eligibility for free testing for COVID-19 and the procedure for its implementation turns out to be "semi-secret", "for friends only", because it is possible to get it from less public sources - chatbots in messengers, official websites of state authorities or public organizations, etc. In such circumstances, due to the inability to use digital technologies, older persons are limited in obtaining relevant information about medical care. Information about the schedule of biomaterial sampling for free testing, availability of free tests in family medicine outpatient clinics, etc. is even more difficult to get for people who are not healthcare professionals, which makes it difficult for them to exercise their respective rights and forces them to apply for paid testing services.

Special attention should be paid to informing residents of the temporarily occupied territories about the right to free testing. In the occupied territories, there is an objective problem with the blocking of the websites of Ukrainian government agencies and the functioning of Ukrainian mobile operators, which negates the effectiveness of even the existing "semi-secret" information channel that exists on the territory controlled by Ukraine. Moreover, the procedure for crossing the demarcation line of the temporarily occupied territory of Ukraine envisages the mandatory negative result of the test for COVID-19. However, it is not possible to carry out testing in the occupied territory, and thus the relevant testing centers (points) are located directly on the contact line. Since 
March 2021, citizens crossing the contact line have been given the opportunity to pass free rapid testing, provided that they download the mobile application "Vdoma" on their smartphone. Therefore, if such a person does not have a smartphone, which is very common among the elderly, they do not have the right to free testing, which is a manifestation of discrimination based on their place of residence and abuse of the monopoly position of these diagnostic centers (points). Taking into account the peculiarities of the legal regime of this territory and the existing uncertainty about the mechanism for exercising powers by non-military public administration agencies, including monitoring compliance with legislation on countering COVID-19, this problem is not easy to solve.

The principle of equal rights in business. The business sector has experienced the devastating effects of the COVID-19 pandemic. Almost all measures to counteract the spread of the virus (quarantine, adaptive quarantine, weekend quarantine, lockdown, etc.) contained restrictions on business activities. Understanding the objective need to minimize contacts between people, which was achieved in this way, one cannot but notice their negative impact on the poverty level, the increase in unemployment, the decrease in financial opportunities to support medical institutions and the field of scientific research, i.e. those key markers that determine the sustainability of the country's development. However, in the medium and long term, even greater harm can be caused by the inequality of the restrictive burden on business, which creates a deepening of general inequality in society, destroys the competitive environment, contributes to the emergence of new prerequisites for corruption, etc.

The legal foundations of the principle of equal rights of companies to protect property in the context of countering the spread of COVID-19, regardless of geographical, economic or any other factor, are laid down in the current national legislation, first, the Constitution of Ukraine (Verkhovna Rada of Ukraine, 1996) and the Commercial Code of Ukraine (Verkhovna Rada of Ukraine, 2003), as well as the Convention for the Protection of Human Rights and Fundamental Freedoms ratified by Ukraine (Council of Europe, 1950). Some essential provisions are enshrined in the UN Guiding Principles on Business and Human Rights (United Nations General Assembly, 2015).

The assessment of equality of business rights should take into account the restrictive factors established by national and international law. In particular, according to the Commercial Code of Ukraine, the right to entrepreneurship can be restricted by law according to the object criterion (spheres of the economy that are sensitive for security reasons) and the subject criterion (in relation to state authorities and local self-government) (Verkhovna Rada of Ukraine, 2003). In Ukraine, the quarantine measures introduced did not apply to prohibited activities. Quarantine restrictions concerning state authorities and local self-government agencies will not be considered in this article. Thus, the results of the analysis can be extended to the business sphere without any exceptions.

The Convention for the Protection of Human Rights and Fundamental Freedoms provides for the possibility of deviation from the general principle of equality of economic rights, in the event of an emergency or natural disaster threatening the life or well-being of the population, to which the COVID-19 pandemic can be attributed, but such a deviation requires the adequacy of the degree of threat and compliance with other international obligations. Therefore, the COVID-19 pandemic should not be used as a 
convenient screen for attacking fundamental human rights and redistributing markets. Given the limited information about COVID-19, the main preventive measure in Ukraine was to minimize direct contacts between people with respect for human rights, which should be provided equally by all companies. Determining the general mechanism for ensuring the safe functioning of the economy is the prerogative of the state, which establishes certain restrictions on the freedom of entrepreneurship, taking into account the current epidemiological situation. In an ideal scenario, state intervention in legitimate business activities is not a positive factor, but the pandemic situation has significantly shifted priorities and requires strengthening the regulatory functions of the state. As in other cases of restrictions on rights, it is critically important to determine the "red lines" of interaction between the state and business, which cannot be interceded under any conditions without appropriate compensation.

An analysis of the UN Guiding Principles on Business and Human Rights allows concluding that the introduction of a three-tiered model of state participation in creating a safe environment is not a violation of the equality of rights of companies, namely: 1) at the first (basic) level, all companies, taking into account the uniform regulatory requirements for the permitted degree of intensity of contact interaction, will independently ensure the proper organization of their own business or, if impossible, temporarily stop their activities; 2) at the second one, more thorough state control over compliance with these regulatory requirements is carried out by companies with which government contracts have been concluded or in whose interests special legislation is adopted, in the case when their activities may affect human rights (transport, medical companies, etc.) etc.); 3) at the third level, additional measures may be taken or additional regulatory security requirements may be established in relation to state-owned companies, as well as companies that are controlled by the state or private companies that receive significant government support and/or use on favorable terms the services of government institutions for lending, export insurance, investment guarantees, etc. (United Nations General Assembly, 2015).

By establishing additional requirements/additional control over their compliance at the second and third levels, the state has the opportunity to compensate the relevant companies for the losses incurred. This compensation must be carried out using those incentive instruments that are already used in relations between them (government contracts, loans, etc.). Thus, state intervention in the form of providing compensation to certain companies will not have an additional impact on the state of competition that has developed in the relevant market in the pre-pandemic period. Recent economic studies indicate the danger of competition disruption during the COVID-19 pandemic, which will increase the market power of large companies, which, at least in Ukraine, usually enjoy state support. In turn, this may slow down the recovery from the crisis in the postpandemic period, holding back innovation and investment (Georgieva, Díez, Duval \& Schwarz, 2021) Another important criterion for the functioning of this three-tiered model of interaction between the state and business is to ensure the immutability of the scope of human rights when establishing prohibitions and restrictions on business activities.

The above-mentioned three-tiered model is the basis of Ukrainian legislation on countering the COVID-19 pandemic. However, additional "layering", which was carried out to prevent the deepening of the crisis in certain sectors of the economy, on the one 
side, and the aggravation of the epidemiological situation, on the other side, unbalanced the mechanism for ensuring equality of rights in business.

The main measures to counteract the COVID-19 pandemic in the business sector in Ukraine are a temporary ban on the activities of companies and the introduction of temporary restrictions on activities of a quantitative or qualitative nature. However, their use, for the most part, is devoid of a single logic, which leads to an unjustified violation of the principle of equal rights of companies.

As an example, the ban on the activities of resort enterprises, which during the New Year holidays did not apply to ski resorts, despite their predominant location in the "red" quarantine zone; the prohibition of trade and services was introduced not based on the possibility of ensuring social distancing but based on the type of product/service and the form of business organization, which provides non-market advantages to large retail chains that simultaneously trade goods of a permitted group (legally) and goods of a prohibited group (using various schemes such as a formal online order that is done next to the checkout in the same store).

The consequence of such a selective approach on the part of the state is negative trends in the retail market, namely: a drop in the attractiveness of this type of economic activity, as evidenced by a decrease in registrations of new companies by $20 \%$ compared to 2019 and an increase in the liquidation of small businesses, in particular, individual entrepreneurs by $16 \%$. It should be noted that to prevent such a situation, certain groups of entrepreneurs (groups I and II of single taxpayers who fulfilled their obligations to contribute to mandatory state social insurance) were provided with state assistance in the form of direct cash payments for the maintenance of children under 10 years of age (Cabinet of Ministers of Ukraine, 2020), which only aggravated the problem with the equality of rights of other persons (taxpayers of other groups, entrepreneurs who do not have children or have disabled children of another age, parents-employees who lost their jobs due to the pandemic, etc.), the efficiency of spending 514.8 million UAH in conditions of limited public funds (Ministry of Social Policy, 2020), but did not have the expected effect.

Signs of delayed self-liquidation of medium-sized and even large trading companies are also of concern because according to statistics, $28.1 \%$ of them received uncompensated financial losses as a result of quarantine restrictions (State Statistics Service of Ukraine, 2020). Reduced competition in the retail food market allowed one of the largest retail chains to announce a price increase of 5-25\%, which, against the background of increasing unemployment (from 8.9\% in Q1 2020 to 9.7\% in Q3 2020), threatens to worsen the socio-economic situation in the country.

The introduction of quantitative restrictions on business activities is based on the principle of equality of all companies, but equality within one branch of the economy or one type of economic activity. Thus, fitness centers can receive visitors if they provide $20 \mathrm{~m}^{2}$ per person, and museums and exhibition halls $-10 \mathrm{~m}^{2}$ per person. At the same time, transport companies must carry out passenger transportation in an amount not exceeding $50 \%$ of seats, i.e. ensuring the established mandatory minimum social distance between passengers is not crucial. This approach does not create objective prerequisites for market redistribution, but it is not effective in terms of quarantine measures.

According to the reporting information for 2020, the number of passengers carried by all 
modes of transport amounted to 60.3\% compared to 2019 (State Statistics Service of Ukraine, 2020). Such a drop is distributed relatively evenly between companies of different modes of transport, which in the short term does not violate the state of interspecific competition, but in the medium term, it can lead to the marginalization of the entire passenger transportation market, because the legislation does not contain any mechanism for compensating losses incurred as a result of the established restrictions. In the postpandemic period, financially drained carriers are unlikely to be able to introduce new technologies, thereby losing their competitive advantages in the market.

Qualitative restrictions that have been introduced in Ukraine consist in influencing the regime of business activities and in their current form are unacceptable from the point of view of observing the principle of equal rights in business, prohibiting unjustified state interference in business activities, as well as in some cases - respect for basic human rights. Special attention should be paid to the restrictions that have been introduced in the energy sector, most of which are not directly related to the purpose of quarantine measures. In particular, it is about restrictions imposed by the government on the entry and exit of the population to satellite cities where nuclear power plant personnel live on the grounds of countering the spread of COVID-19 (Cabinet of Ministers of Ukraine, 2020). First, any disease, including COVID-19, cannot serve as an excuse for violating human rights, in particular, freedom of movement, which provides that everyone who is legally located on the territory of any state, within this territory, has the right to move freely and choose their place of residence (United Nations General Assembly, 2015). Second, any restrictions based on place of residence or other grounds are considered discrimination and are unacceptable. Third, restriction of freedom of movement, like any other constitutional right in Ukraine, is possible solely based on the law, and not a subordinate act. Fourth, as operational information and statistical information show, there were no outbreaks of COVID-19 in satellite cities separately or as part of larger settlements either at the time of the introduction of restrictions or during the entire period of their validity, which would indicate the need for such isolation of these territories. Thus, today there are no arguments in favor of the adequacy of the introduced measure to the existing degree of threat, which should justify the violation of freedom of movement.

It should be noted that the attempt to introduce restrictions on freedom of movement for all citizens ended in failure. The relevant regulatory legal act of the government was considered by the Constitutional Court of Ukraine and declared unconstitutional. In particular, the court noted that restriction of constitutional rights and freedoms is possible in cases stipulated by the Constitution of Ukraine and can only be established by law. The establishment of such a restriction by a subordinate act contradicts the Constitution of Ukraine (Constitutional Court of Ukraine, 2020). However, the restriction of the right of movement in satellite cities was introduced by another regulatory legal act of the government, which was not the subject of consideration in the Constitutional Court of Ukraine, i.e. its compliance with the Constitution of Ukraine was not verified, and therefore the issue of discrimination against residents of such satellite cities remains open. The second group of violations of the principle of equality in the energy sector concerns the economic rights of companies. In particular, we consider the establishment of a temporary ban (from May 20, 2020 to July 22, 2020) on electricity suppliers to apply sanctions in the form of shutdowns and restrictions below the technological minimum of 
electricity consumption in contractual relations with a centralized water supply and sewerage enterprises, coal mining enterprises. In relation to suppliers of natural gas, in addition to the specified prohibition, a requirement was also introduced to conclude and execute a contract for the supply of natural gas with a producer of heat and electricity, regardless of their compliance with the terms of calculations (Cabinet of Ministers of Ukraine, 2020).

The right to independently choose counterparties under contracts, determine the terms of such contracts and receive fair compensation for violations of their contractual rights and legitimate expectations are key elements of freedom of entrepreneurship, on which, in turn, the market economy is based. By introducing quarantine restrictions in the energy sector, the government made it impossible to implement the existing legal right of the energy supplier to compensation from the energy consumer. At the same time, such deprivation of the right occurred not only for a certain period in the future, when the energy supplier has the opportunity to adjust its business strategy, minimizing potential losses, but also for the rights of claim that arose in the past but have not yet been implemented not through the fault of the injured party, in respect of which it will no longer be possible to introduce mitigation measures. Therefore, the imposed restrictions lead to consequences that have signs of violation of legitimate expectations, which is one of the types of violation of the right to protection of property guaranteed by the First Protocol to the Convention for the Protection of Human Rights and Fundamental Freedoms. Deprivation of this right can be considered legitimate if it occurs in the public interest and under the conditions provided for by law and general principles of international law (Council of Europe, 1950). However, the circumstances of the introduction of restrictions do not indicate the existence of these grounds.

\section{Conclusions}

COVID-19, like a litmus test, revealed systemic flaws not only in special legislation on countering the pandemic, but also in the legal system of Ukraine as a whole, which is an obstacle to the country's sustainable development.

The analysis showed that, despite a significant updating of legislation, in particular, in terms of ensuring human rights, the conceptual principles on which they are based (the principle of equality) remained rejected. Under such conditions, the implementation of the general goal "No one will be left behind" faces uncertainty about the content of "no one", because, as the analysis shows, not all individuals and legal entities are covered by proper guarantees.

Unjustified restrictions on the principle of equal rights of citizens to medical care have been identified. In particular, this applies to determining the circle of people who are entitled to free testing for COVID-19, creating conditions for obtaining information about the rights of citizens in matters of protection from COVID-19, during treatment in healthcare institutions. Discrimination is based on age and place of residence (residents of the occupied territories when crossing the demarcation line).

Non-compliance with the principle of equality is also inherent in the legislation that defines the operation of companies in conditions of fight against COVID-19. There is a significant difference in legislative approaches to restrictions on freedom of entrepreneurship within 
the economy as a whole, individual industries, and even at the level of individual companies.

The reasons for the violation of the principle of equal rights of citizens to health care are mainly in the plane of the competence of the special management agency, in particular, the lack of a comprehensive vision of the pandemic countermeasures mechanism, which leads to a chaotic distribution of financial resources and medicines without taking into account the real need for them, as well as lack of communication at all levels. In business, negative results are primarily due to the violation of the boundaries of the existing competence of the rule-making body, which leads to both a narrowing of the "window of opportunity" for companies regarding sustainable development in the post-pandemic period and a worsening of the situation with the protection of fundamental human rights in the state as a whole.

\section{References}

Amadasun, S. (2020). COVID-19 palaver: Ending rights violations of vulnerable groups in Africa. World Development, Volume 134, 2020, 105054, https://doi.org/10.1016/j.worlddev.2020.105054.

Bautista-González, E., Werner-Sunderland, J., Pérez-Duarte Mendiola, P., Esquinca-Enríquez-de-la-Fuente, C., Bautista-Reyes, D., Maciel-Gutiérrez, M., Murguía-Arechiga, I., Vindrola-Padros, C. \& Urbina-Fuentes, M. (2021). Health-care guidelines and policies during the COVID-19 pandemic in Mexico: a case of health-inequalities. Health Policy OPEN, 2, 100025. https://doi.org/10.1016/i.hpopen.2020.100025.

Cabinet of Ministers of Ukraine. (2020). Certain aspects of social support for families with children: Resolution of the Cabinet of Ministers of Ukraine of April 22, 2020. Retrieved from https://zakon.rada.gov.ua/laws/show/329-2020-п

Cabinet of Ministers of Ukraine. (2020). On quarantine to prevent the spread of acute respiratory desease COVID-19 caused by a coronavirus SARS-CoV-2 on nuclear power plants of Ukraine: Resolution of the Cabinet of Ministers of Ukraine of March 16, 2020. Retrieved from https://zakon.rada.gov.ua/laws/show/240-2020-\%D0\%BF\#Text

Cabinet of Ministers of Ukraine. (2020). On quarantine to prevent the spread of acute respiratory disease COVID-19 caused by coronavirus SARS-CoV-2: Resolution of the Cabinet of Ministers of Ukraine of May 20, 2020. Retrieved from https://zakon.rada.gov.ua/laws/show/392-2020$\% \mathrm{D} 0 \% \mathrm{BF} / \mathrm{ed} 20200801 \#$ Text

Constitutional Court of Ukraine. (2020). Decision of the Constitutional Court of Ukraine in the case on the constitutional petition of the Supreme Court on the constitutionality of certain provisions of the Resolution of the Cabinet of Ministers of Ukraine "On quarantine to prevent the spread of acute respiratory disease COVID-19 caused by coronavirus SARS-CoV-2, and stages event of August 28, 2020. Retrieved from https://zakon.rada.gov.ua/laws/show/v010p710-20\#Tex.

Drezner, D. (2020). The Song Remains the Same: International Relations After COVID-19. International Organization, 1-18. https://doi.org/10.1017/S0020818320000351

European Convention for the Protection of Human Rights and Fundamental Freedoms of November 04, 1950. Retrieved from https://www.coe.int/uk/web/compass/the-european-convention-onhuman-rights-and-its-protocols

Fazal, T. (2020). Health Diplomacy in Pandemical Times. International Organization, 1-20. https://doi.org/10.1017/S0020818320000326

Fisher, E., Shapiro, S. (2021). Administrative Competence Reimagining Administrative Law. University of Cambridge Faculty of Law Research Paper. Retrieved from https://ssrn.com/abstract=3802112

Georgieva, K., Díez F., Duval, R. \& Schwarz, D. (2021) Rising Market Power-A Threat to the Recovery? IMFBlog International Monetary Fund. Retrieved from https://blogs.imf.org/2021/03/15/risingmarket-power-a-threat-to-the-recovery

Goldmann, M. (2020). The European Economic Constitution after the PSPP Judgment: Towards Integrative Liberalism? German Law Journal, 21 (5), 1058-1077 https://doi.org/10.1017/gli.2020.64 
Hambleton, R. (2020). Cities and Communities Beyond COVID-19: How Local Leadership Can Change Our Future for the Better (pp. 25-52). Bristol University Press.

Hoernke, K. (2020). A socially just recovery from the COVID-19 pandemic: a call for action on the social determinants of urban health inequalities. J R Soc Med. 2020 Dec; 113(12): 482-484. Published online 2020 Sep 11. doi: 10.1177/0141076820948817

Lebret, A. (2020). COVID-19 pandemic and derogation to human rights, Journal of Law and the Biosciences, Volume 7, Issue 1, January-June 2020, lsaa015, https://doi.org/10.1093/jlb/lsaa015

Lipscy, P. (2020). COVID-19 and the Politics of Crisis. International Organization, 1-30. https://doi.org/10.1017/S0020818320000375

Ministry of Economic Development and Trade of Ukraine. (2017). National Report 'Sustainable Development Goals: Ukraine' of September 15, 2017. Retrieved from http://sdg.org.ua/ua/resources-2/274-2017

Ministry of Health of Ukraine. (2020). On Road Map for coronavirus COVID-19 vaccine and mass vaccination against acute respiratory disease COVID-19 caused by a coronavirus SARS-CoV-2 in Ukraine on 20212022 of December 24, 2020. Retrieved from https://zakon.rada.gov.ua/rada/show/v3018282-20\#Text

Ministry of Health of Ukraine. (2020). Organization of medical care for COVID-19 patients of March 28, 2020. Retrieved from https:// zakon.rada.gov.ua/rada/show/v0722282-20 - Text

Ministry of Social Policy of Ukraine. (2020). Report on implementation of budget programs passport on 2020. Retrieved from https://www.msp.gov.ua/news/19668.html

National Health Service of Ukraine. (2021). Information about medicins for prevention of emergence and spread of acute respiratory disease COVID-19. National Health Service of Ukraine. Retrieved from https://nszu.gov.ua/e-data/dashboard/covid-drugs-inventory

Repullo, J.R. (2021). The medical profession in the face of the reactivation of the COVID-19 pandemic in Spain. Journal of Healthcare Quality Research, 36, 1. https://doi.org/10.1016/i.jhqr.2020.11.002

Sachs, J., Schmidt-Traub, G., Kroll, C., Lafortune, G., Fuller, G. \& Woelm, F. (2020). The Sustainable Development Goals and COVID-19. Sustainable Development Report. Cambridge University Press. 510 p. https://doi.org/10.1111/PADR.12366

State Statistics Service of Ukraine. (2020). Financial results before taxation of large and medium enterprises by type of economic activity January-September 2020. Retrieved from http://www.ukrstat.gov.ua Loperativ/operativ2020/fin/fin rez/fr ed/fr ed u/arh fr edo2020 u.htm

State Statistics Service of Ukraine. (2020). Passenger-kilometres performed, by type of transport, 2020. Retrieved from http://www.ukrstat.gov.ua/operativ/operativ2019/tr/tr rik/po v/arh po v u.htm

Tedros, A.H. (2021). Who Director-General's opening remarks at 148 th session of the Executive Board. World Health Organization. Retrieved from https://www.who.int/director-general/speeches/detail/whodirector-general-s-opening-remarks-at-148th-session-of-the-executive-board

United Nations General Assembly. (1948). Universal Declaration of Human Rights: General Assembly resolution of Desember 10, 1948. Retrieved from https://www.un.org/sites/un2.un.org/files/udhr.pdf

United Nations General Assembly. (1966). International Covenant on Civil and Political Rights: General Assembly resolution of Desember 10, 1966. Retrieved from https://www.un.org/en/development/desa /population/migration/generalassembly/docs/globalcompact/A RES 2200A(XXI) civil.pdf

United Nations General Assembly. (1986). Declaration on the Right to Development: General Assembly resolution of Desember 04, 1986. Retrieved from https://undocs.org/en/A/RES/41/128

United Nations General Assembly. (2015). Transforming our world: the 2030 Agenda for Sustainable Development: General Assembly resolution of September 25, 2015. Retrieved from https://undocs.org/en/A/70/L.1

Verkhovna Rada of Ukraine. (1996). Constitution of Ukraine of 28 June, 1996. Retrieved from https://zakon.rada.gov.ua/laws/show/254\%D0\%BA/96-\%D0\%B2\%D1\%80

Verkhovna Rada of Ukraine. (2000). On protection of the population from infectious diseases of April 6, 2000. Retrieved from https://zakon.rada.gov.ua/laws/show/1645-14\#Text

Verkhovna Rada of Ukraine. (2003). The Commercial Code of Ukraine of January 16, 2003. Retrieved from https:// zakon.rada.gov.ua/laws/main/436-15?lang=en\#Text

Zolka, V., Tsarenko, O., Kushnir, I., Tsarenko, S. \& Havrik, R. (2021). The Impact of the Pandemic Covid19 on the Human Right to Freedom of Movement. European Journal of Sustainable Development, 10 (1), 376. https://doi.org/10.14207/ejsd.2021.v10n1p376 